\title{
Essential Role of Horticulture in Rare Plant Conservation
}

\author{
James M. Affolter ${ }^{1}$ \\ Department of Horticulture and The State Botanical Garden of Georgia, University of Georgia, \\ 2450 S. Milledge Avenue, Athens, GA 30605
}

\begin{abstract}
Conservation of rare plant species has been a field of active investigation, experimentation, and debate during the last quarter century. As patterns and rates of plant extinction have been increasingly well documented, numerous theoretical and applied studies have considered demographic, genetic, evolutionary, and economic consequences of reduction in number and size of plant populations, as well as alternative methods for pursuing and prioritizing conservation efforts (Elias, 1987; Falk and Holsinger, 1991; Phillips and Meilleur, 1995; Simmons et al., 1976; Synge, 1981; Yatskievych and Spellenberg, 1993). Ultimately, preservation and enhancement of rare plant populations is a management problem, requiring typically a combination of onsite and off-site activities (Falk, 1990; Holsinger and Gottlieb, 1991). Horticultural science has an essential role to play in the conservation of rare plants; but, to date, formal horticultural research in this field has taken place on a fairly limited basis. Plant conservation as a scientific and practical discipline would benefit greatly from broader application of the rigorous approach characteristic of commodity-oriented horticultural research. This article provides an introduction to plant conservation efforts in the United States for horticultural scientists and students. For a comprehensive discussion of plant conservation strategies from an international perspective, see Given (1994).
\end{abstract}

\section{HOW MANY PLANT SPECIES IN THE UNITED STATES ARE AT RISK?}

On a worldwide scale it has been estimated that during the next 2 to 3 decades global extinction rates for plants may average 2000 species annually (Raven, 1987). In the continental United States, an estimated 90 species of vascular plants have become extinct during the past 200 years (Ayensu and DeFilipps, 1978). The U.S. Fish and Wildlife Service currently lists 526 native plant taxa as threatened or endangered (U.S. Fish and Wildlife Service, 1995), but the number of species tracked by conservation organizations and state Heritage Programs is far higher. The Center

\footnotetext{
Received for publication 10 June 1996. Accepted for publication 2 Oct. 1996. I gratefully acknowledge the following for sharing their experience and insights through conversations and/or preliminary reviews of the manuscript: Matt Albright, Jennifer Ceska, Jeff Lewis, Brien Meilleur, Cathy Pringle, Tammera Race, John Ruter, and Susan Wallace. The cost of publishing this paper was defrayed in part by the payment of page charges. Under postal regulations, this paper therefore must be hereby marked advertisement solely to indicate this fact. 'Assistant Professor.
}

for Plant Conservation considers $\approx 4000$ species, or one-fifth of our native flora, to be of conservation concern (B. Meilleur, pers. comm.). A Center for Plant Conservation survey of 130 botanists and horticulturists in 1988 identified 680 plant species in the United States likely to become extinct by the year 2000 (Roberts, 1988). Nearly three-fourths of these critically endangered plants were found in just four states, Hawaii, California, Texas, Florida, and in Puerto Rico. The Nature Conservancy data base for the United States lists 1,013 vascular plant taxa as being known from five or fewer populations or fewer than 1000 individuals (The Nature Conservancy, 1996).

\section{WHAT ROLE DOES HORTICULTURE PLAY IN THE CONSERVATION OF RARE PLANTS?}

Most efforts to conserve rare plants involve some form of intervention with natural populations. This may be nondestructive, such as taking a census or observing pollinators, or it may involve significant modification of the habitat, such as controlled burning in fireadapted communities. Any research or conservation projects that involve propagating or maintaining living specimens of rare plants outside their natural habitats are likely to involve activities traditionally associated with horticultural science. Relevant fields of study include seed technology, propagation and tissue culture, mineral nutrition, growth regulation, soil management, and protection from pests and diseases. Even when the primary goal of conservation research is not horticultural knowledge, it is often necessary to develop techniques for cultivating a rare species as a means to an end. For example, in an ecological study concerning causes of rarity, Aplet and Laven (1993) collected seeds of rare and common Hawaiian shrub species and grew various combinations in pots to compare competitive ability. In a study of genetic diversity in the rare mallee species Eucalyptus crucis Maiden, Sampson et al. (1988) grew seedlings from wild-collected seed to obtain fresh tissues for electrophoretic analysis.

Plant conservation biologists and land managers often make the distinction between on-site and off-site activities (also referred to as in situ vs. ex situ). Comprehensive recovery and management plans combine the two in what have been termed "integrated conservation strategies" (Falk, 1987). Although there is general agreement that long-term survival of endangered species is best assured by preserving natural habitat, off-site activities involving horticultural technology often provide an essential stepping stone on the path to recovery. In extreme cases, ex situ conservation collections of germplasm are the last line of defense against extinction. The Hawaiian flora, which has already lost $\approx 100$ species to extinction (Wagner et al., 1990), provides many striking examples. Habitat loss and the impact of introduced species, combined with the extremely high level of endemism in the Hawaiian archipelago, have reduced dramatically the number and extent of many native plant populations. The flora now includes at least 12 taxa that have only one known plant left in the wild and 110 taxa with 20 or fewer individuals remaining in the wild (Center for Plant Conservation, 1994; Ray, 1995). In such circumstances, the significance of conserving rare species as ex situ germplasm is apparent. In the following discussion I will use the term "conservation horticulture" to refer to the application of the techniques and knowledge base of horticulture to rare plant conservation.

\section{WHERE IS MOST HORTICULTURAL RESEARCH IN CONSERVATION CURRENTLY TAKING PLACE?}

Many individuals and organizations currently propagate, grow, and study rare plants for conservation purposes. These include nonprofit conservation groups (e.g., Center for Plant Conservation, The Nature Conservancy, National Wildflower Research Center), government agencies (e.g., National Park Service, U.S. Natural Resources Conservation Service, National Forest System, state Natural Heritage Programs), commercial native plant nurseries and seed suppliers, native plant societies, and garden clubs. The National Wildflower Research Center's Wildflower Handbook (1992) provides an extensive list of conservation organizations and governmental agencies that work with native plants.

Botanical gardens and arboreta are among the most active participants in endangered plant research. Like zoos, these organizations have embraced conservation of rare species as one of their primary missions. Active regional, national, and international networks have been established to coordinate conservation programs in gardens and arboreta, build data bases, disseminate information, and establish guidelines and standards (Given, 1994; New England Wildflower Society, 1992). Notable examples include the Center for Plant Conservation in the United States (CPC) at the Missouri Botanical Garden, St. Louis, and Botanic Gardens Conservation International (BGCI) based at Kew Gardens, United Kingdom. Thanks in large part to activities of these organizations, the quality of plant conservation research has increased steadily, particularly among their member institutions, and as a result of collaborative relationships they have established with research and governmental institutions. 
In spite of this progress, the majority of conservation horticulture activities carried out around the world today are not designed or implemented as formal scientific studies. Often the immediate objectives of a particular project do not require this approach. The purpose of propagating a rare plant may be simply to obtain a few specimens for display or distribution. In other instances, projects address questions that lend themselves well to formal investigation, but participants lack the training, time, interest, or resources (equipment, space, technical assistance) to conduct an experimental study. Organizations such as the $\mathrm{CPC}$ and $\mathrm{BGCI}$ have played a valuable role in establishing standards for documentation, study, and maintenance of rare plant collections through publications, conferences, and activities of their scientific advisory committees (Botanic Gardens Conservation Secretariat, 1989; Falk and Holsinger, 1991; Heywood and Jackson, 1991; Wieland, 1995). More widespread participation in rare plant research by the academic horticulture community would enhance further the quality of plant conservation as a scientific discipline.

Most of the refereed scientific literature concerning rare plants is found in journals in the fields of botany, ecology, genetics, natural resource management, and conservation biology. Studies concerning native plants have been published in recent volumes of HortScience and the Journal of the American Society for Horticultural Science, but only a handful of these have dealt with rare species, e.g., with micropropagation studies (Anthony, 1992; Bunn and Dixon, 1992; Clayton et al., 1990).

\section{HOW WOULD THE FIELD OF PLANT CONSERVATION BENEFIT FROM MORE ACTIVE PARTICIPATION BY THE ACADEMIC HORTICULTURE COMMUNITY?}

Many plant conservation programs fail to take advantage of the power of the scientific method in designing and evaluating conservation projects. This approach is, however, fundamental to most commodity-oriented horticultural research and is applied easily to similar investigations involving endangered species. Studies designed to test statistically clearly defined hypotheses are likely to be: 1) better documented, 2) more accurately interpreted, 3) easier to compare to other studies, 4) more convincing, and 5) more easily disseminated. Successful results are also more likely to be reproducible by others working with the same, related, or ecologically similar species.

Plant conservation also stands to benefit enormously from the knowledge base, theory, and technical expertise of horticultural science. Horticultural scientists working in universities and other research laboratories work typically with plants of direct economic importance. Their skills and knowledge can be applied with equal effectiveness to species that are valued for other characteristics.

In some cases, the objectives of conservation horticulture are different from those of traditional commodity-oriented research, but the techniques and theory remain equally applicable. The different ways in which commodity-based horticulture and conservation horticulture manipulate genetic diversity illustrate this point. Development of new commodity crops and cultivars often involves selection and breeding programs that are designed to narrow the spectrum of genetic diversity found in nature. Research programs are designed to achieve uniformity in plant size, flowering and fruiting phenology, chemical composition, or morphology. The overall pattern is from greater genetic diversity (in nature) to less diversity (in cultivation). Conversely, conservation biologists often begin with a very limited pool of genetic diversity in natural populations then look for the most effective ways to maximize the conservation of this diversity, through on-site or off-site activities. From the point of view of horticultural science, these two objectives are different sides of the same coin-the same technologies, theoretical principles, and knowledge base apply in either case. The tools of modern horticultural science have been used very effectively to channel biodiversity to useful ends. The field of conservation biology would benefit greatly if those same tools were used to slow the erosion of biodiversity in native plant species.

\section{HOW WOULD HORTICULTURAL SCIENTISTS BENEFIT BY PLAYING A MORE ACTIVE ROLE IN RARE PLANT RESEARCH?}

The profession of horticultural science has a great deal to gain by participating more actively in plant conservation programs. Benefits include an influx of new ideas, new people, and new resources.

Interaction with other scientific disciplines. Conservation biology is highly interdisciplinary and often provides a basis for new collaborations and an influx of new perspectives. At the University of Georgia, faculty and students in the schools and Departments of Ecology, Botany, Genetics, Forestry, Geography, Environmental Design, Anthropology, and Horticulture are involved in rare plant conservation projects, often collaboratively.

Access to new funding sources. In today's economic climate, most researchers are looking for opportunities to diversify their sources of funding. Many agencies that fund research and training programs in conservation biology would not be thought of as traditional sources of support for horticultural research programs. These include federal and state agencies as well as many private and corporate foundations. References such as "Environmental Grantmaking Foundations" (Environmental Data Research Institute, 1995) publish information on hundreds of funding organizations that include environmental projects among their top priorities. Horticultural aspects of my own research with rare native species (e.g. Spigelia gentianoides Chapm.) have been funded by The Nature Conservancy and the National Biological Survey. The Center for Plant Conservation regularly has funded rare plant research and is actively seeking research collaborations, particularly in the fields of rare plant genetics, seed storage technology, seed physiology, and micropropagation (B. Meilleur, pers. comm.).

Expansion of the pool of undergraduate and graduate students. Many students at the university level are interested in environmental issues, but are unaware that formal training in horticultural science can provide them with tools and insights for pursuing this interest. My own experience suggests that most undergraduates majoring in biology, botany, ecology, forestry, or anthropology have little understanding of what the science of horticulture encompasses, yet they often become interested in specific subjects where the theory and techniques of horticultural science are highly relevant. Many of these students respond enthusiastically when given the opportunity to work directly with living plants, an approach that often receives more emphasis in horticulture than in these other disciplines.

Courses emphasizing the role of horticulture in plant conservation and preservation of biodiversity are likely to attract and introduce a new pool of students to the science of horticulture. We offered a course at the Univ. of Georgia in 1995 (cross-listed in the Depts. of Horticulture and Anthropology) titled "Biodiversity of the World's Food Crops: A Multilevel Analysis." This team-taught course explored the dependence of the world's food supply on genetic diversity in natural populations and traditional landraces of cultivated plants. The subject was addressed from three levels of analysis: molecular, organismal, and cultural. By the end of the course, anthropology students enrolled in the course had a new appreciation for the role of horticultural research in preserving biodiversity, and they requested more information concerning mainstream horticulture courses that would complement their research interests (e.g., vegetable crops, plant breeding, postharvest physiology).

Service to a growing industry segment and consumer interest. Rare plants are a subset of a much larger group of plants-native species-that are becoming increasingly important in commercial horticulture (e.g., Martinez, 1995; Phillips and Meilleur, 1995; Thomas, 1993a; Van de Water, 1995). Design and maintenance trends that encourage use of native plants in the landscape, such as xeriscaping, will continue to build consumer interest and demand. Legal restrictions and mitigation regulations that require developers to restore or replace plant and animal communities create markets for large volumes of native plant species that do not necessarily have a history of commercial production (Sauer, 1995a, 1995b; Thomas, 1993b). Although acceptance in the marketplace ultimately depends upon many factors, native species benefit from the same research and marketing approaches that are applied to exotic species (Bir, 1996).

Federal and state mandates concerning use of native species for landscaping and restoration projects have stimulated numerous feature articles and opinion pieces in industry 
publications (e.g., Hensley, 1993; Koller, 1992). President Clinton sparked additional debate when he issued a memorandum during the 1994 Earth Day celebration requiring the exclusive use of regionally native species on federal grounds and for federally funded restoration projects (Martinez, 1995; Topik, 1994). Opponents of mandates object to initiatives that "require" selection of native species, although many agree that their more widespread use should be "encouraged" (Martinez, 1995). Regardless of how this debate is resolved, it signals a growing market for native species in government-funded programs.

Another debate has surrounded the issue of commercial sale of rare plant species, an activity that some view with skepticism and concern. For species that are protected by the federal Endangered Species Act, permits are required to sell nursery-propagated plants across state lines. Examples of endangered species that are available from nurseries that have obtained permits include Rhododendron chapmanii A. Gray, Conradina verticillata Jennison, and Echinacea tennesseensis Small. An alternative marketing approach is to forgo the permitting process and sell plants only within their state of origin. Woodlanders, a nursery in Aiken, South Carolina, lists 14 federally protected species in their 1996 catalogue, but these nursery-propagated plants are available only in South Carolina. The Convention on International Trade in Endangered Species of Wild Fauna and Flora (CITES) regulates import and export of many important horticultural groups native to North America, including cycads, cacti, and orchids (Given, 1994).

Those who oppose sale of rare plant species on other than legal grounds advance several arguments: 1) commercial production just creates more interest in these little-known plants and encourages people to collect them from wild populations, 2 ) widespread cultivation of rare species might lead to "escapes" that confuse study of their natural distribution and ecology, and 3) gene flow via seed or pollen from cultivated to natural populations of rare plants might contaminate local ecotypes, reducing hardiness or pest resistance of the local ecotype, or otherwise modifying the population genetically (Wilson, 1993).

While it is essential to discourage nurseries from selling wild-collected material of rare plants and to educate the public against obtaining plants in this fashion, arguments in support of commercial propagation and sale of rare plants often outweigh the risks. In the most extreme case, some plants have become so rare in nature that commercial nurseries and public and private gardens represent a primary repository of germplasm. The classic example in the southeastern United States is Franklinia alatamaha Marsh., a small tree with showy white flowers last seen in the wild in 1803 in Georgia (Thomson, 1990). Other species, because of aesthetic or medicinal value, have been harvested from the wild to such an extent that commercial production is necessary to protect the remaining natural populations (Affolter and Lagrotteria, 1995: Bogers and van Leeuwen, 1992; Bonati, 1991; Fuller, 1991; Palevitch, 1991; Winter and Botha, 1994).

Finally, sale of rare plants creates opportunities to educate consumers concerning conservation issues and the importance of preserving regional floras. Many gardeners are attracted by the natural rarity of endangered species in the same way that some people are drawn to "botanicals" rather than cultivated varieties. This interest can be encouraged and used to promote greater concern for preservation of these species in the wild. In practice, the benefits and risks of commercialization of rare plants should be considered on a case-bycase basis, but as the International Botanic Gardens Conservation Strategy asserts: "Commercial horticulture and the nursery trade have an important role in conservation [and] the nursery trade may be regarded as potentially a major ally for plant conservation" (Botanic Gardens Conservation Secretariat, 1989).

Strengthen the environmental component of horticultural science. Conservation horticulture provides an additional opportunity for horticulture as a discipline to address constructively problems of environmental quality and biodiversity at a time when political, legal, and economic pressures for such participation are increasing. The strategic plans of the Univ. of Georgia and its College of Agricultural and Environmental Sciences, for example, place a priority on environmental issues in education, research, and public service. Many funding sources are doing the same. Some might argue that rare plant research falls outside the responsibility of academic departments of horticulture at land grant universities, departments that have traditionally been strongly commodity-oriented. I would argue that few missions are more appropriate for land grant universities than to work to preserve the natural heritage and biodiversity of their state and region, and to the extent that departments of horticulture can contribute to that mission, they should be encouraged.

\section{CASE STUDIES IN CONSERVATION HORTICULTURE}

The following examples illustrate a few of the areas where rare plant conservation is benefiting or could benefit in the future from more active involvement of horticultural scientists. They include on-site and off-site conservation studies.

The Endangered Plant Collection at Bok Tower Gardens, Fla. The staff of Bok Tower Gardens, a participating institution of the Center for Plant Conservation located in Lake Wales, have assembled a research and conservation collection of 36 of the state's endangered species (Wallace, 1995). Many of these rare taxa are endemic to the sandpine/xeric oak scrub communities found in coastal and central Florida (Fig. 1), sites characterized by sandy, nutrient-poor, and well-drained soils (Wallace, 1990). Scrub communities in the interior region of the state occur on remnants of ancient beach and sand dune ecosystems that have been above sea level for as long as 3 million years (Martin, 1993). These habitats have been fragmented and largely eliminated for housing developments, golf courses, and citrus groves. Most species in the Bok Tower endangered plant collection are grown in raised beds, measuring $\approx 3 \times 8 \mathrm{~m}$. The medium in the beds is a sandy loam native to the site, although the staff have experimented with amending soil in some beds. After growing rare species for many generations in these outdoor beds, the staff estimate that one-third of the transplanted species do well in cultivation, one-third show moderate success, and another third do poorly.

While growing relatively many rare plants through several generations, the staff gather considerable information concerning horticultural characteristics of individual species, including: ease of propagation, cultural requirements, pest and disease susceptibility, range of genetic variation in form and habit, and ornamental potential. One species in the Bok Tower collection that has grown well in cultivation is Spigelia gentianoides Chapm., an attractive perennial in the primarily tropical family Loganiaceae (Fig. 2). This federallylisted endangered species survives in only two Florida populations (totaling $<300$ individuals) and in sites recently discovered $300 \mathrm{~km}$ distant in Bibb County, Ala. We are conducting genetic and propagation experiments at the University of Georgia to clarify the extent and pattern of genetic variability in this species as well as its horticultural requirements. Analyses of allozyme diversity using starch gel electrophoresis have allowed us to compare the genetic composition of Florida and Alabama populations and the amount of genetic diversity captured by the off-site collection of this species at Bok Tower Gardens. Controlled and replicated germination studies

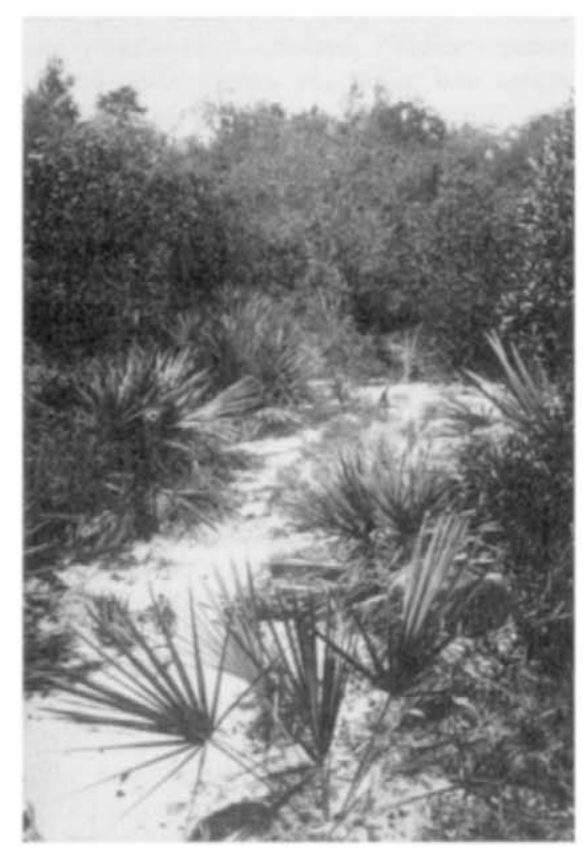

Fig. 1. Species endemic to the sand pine/xeric oak scrub community of central Florida are protected on-site in nature reserves and off-site in cultivation at Bok Tower Gardens. 


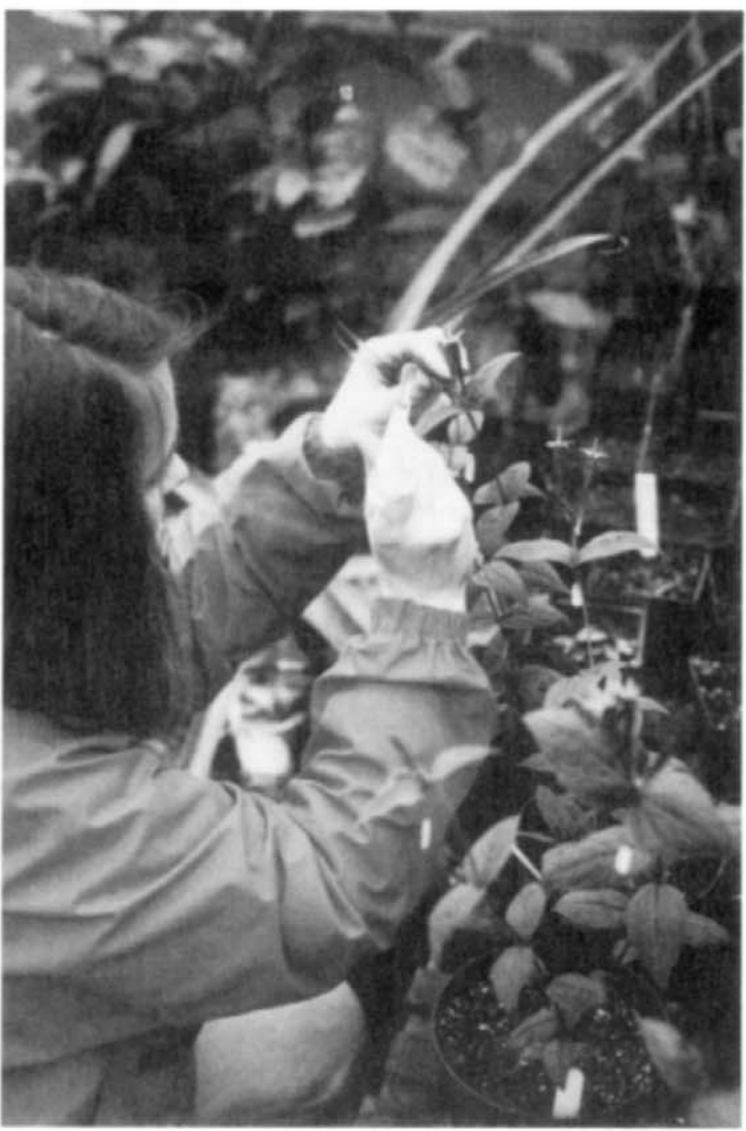

Fig. 2. An undergraduate horticulture student at the Univ. of Georgia performs artificial crosses in Spigelia marilandica L.; the experiment is part of a comparative study of mating systems in this widespread species and the endangered $S$. gentianoides.

using wild-collected seed have analyzed their response to stratification and gibberellic acid treatments. Results of these studies (unpublished) will be used to enhance long-term management of S. gentianoides in natural populations and in off-site conservation collections. Since this is a species with horticultural potential as a garden plant, results may also be used to facilitate introduction of this species into commercial horticulture.

Meadow restoration at Mount Rainier and Olympic National Parks. While this article has focused on rare and endangered species, there is a parallel need for more horticultural research concerning native plants that may not be in immediate danger of extinction but that belong to threatened or stressed natural communities. Efforts by the National Park Service to restore mountain meadow plant communities in the Pacific Northwest provide a model for future efforts. The millions of visitors that hike the trails and slopes of Mount Rainier and Olympic National Parks each year often stray from the established walking paths (a practice park staff refer to as "social trailing"). In the process, they trample native grass and wildflower meadows, destroy plant populations, and enhance erosion along the mountainous slopes. Park revegetation projects have been carried out since the 1980 s to restore the delicate mountain meadows. With the help of hundreds of volunteers, park staff collect seeds and cuttings from plant populations near the areas to be revegetated. These plants are nursery-propagated, then transported by helicopter to back country sites for planting in the fall.

At Mount Rainier, revegetated slopes are covered with a mulch of excelsior to reduce erosion, moderate ground temperature, and retain moisture (Fig. 3). Native species employed in the revegetation process include grasses, sedges, shrubs, trees, and woody groundcovers, including two subalpine heather species-Phyllodoce empetriformis (Sm.) D. Don and Cassiope mertensiana (Bong.) D. Don. By Summer 1995, well over 100,000 native plants had been propagated at Olympic National Park's greenhouse. Park staff state that they have encountered numerous horticultural problems in the course of the revegetation project that would profit from further investigation. Examples include propagation research with native species, measurement and improvement of outplanting success, and evaluation of early vs. late successional species in revegetation plantings. These and similar projects would be excellent topics for undergraduate and graduate research and would demonstrate to students the importance of horticultural research in conservation biology.

The Georgia Plant Conservation Alliance. Cooperative relationships between universities, nonprofit institutions, and government agencies can provide excellent opportunities for horticultural scientists and students to become involved in plant conservation research. We recently formed such an organization in Georgia to coordinate plant conservation efforts on a statewide basis. Charter members of the Georgia Plant Conservation Alliance (GPCA) include four botanical gardens, the Univ. of Georgia, The Nature Conservancy, the U.S. Forest Service, and the state Heritage Program (part of the Dept. of Natural Resources). Three of the initial projects that Alliance members are pursuing collaboratively involve horticultural research. Torreya taxifolia Arn. (Taxaceae), one of the most critically endangered species in the United States, is a tree attacked in the wild by a blight that limits most natural populations to sexually immature root sprouts. Research is required to propagate uninfected individuals and to isolate the disease agent. A second project, conservation of mountain and coastal plain bog communities, involves on- and off-site studies of endemic species of pitcherplant (Sarracenia spp.) (Fig. 4), including genetic analyses, propagation research, and habitat management. Elliottia racemosa Muhlenb. ex Elliott, a small tree or shrub in the Ericaceae with considerable ornamental potential (Del Tridici, 1987; Ruter et al., 1995), is the third subject of horticultural research. This endangered species, endemic to the coastal plain of Georgia, is being investigated to determine mating systems, genetic structure, and requirements for seed germination, seedling establishment, and vegetative propagation in cultivation. The GPCA is an example of how horticultural scientists can work with other organizations involved in plant conservation to gain access to information, plant materials, study sites, technical expertise, and sources of financial support that would otherwise be difficult to obtain.

\section{WHAT CAN BE DONE TO ENCOURAGE PARTICIPATION OF HORTICULTURAL SCIENTISTS IN RARE PLANT CONSERVATION EFFORTS?}

Conservation biology needs input from horticultural scientists, and conservation horticulture provides many opportunities for our profession. As an organization and as a discipline, we can take the following steps to encourage research in this field:

- Form an ASHS working group on endangered plant species to address issues of conservation horticulture.

- Invite representatives of conservation organizations to address meetings of horticulture scientists, from university departmental seminars to regional and national conferences.

- Encourage publication of articles in HortScience and the Journal that deal with conservation horticulture, applying the same peer-reviewed standards to these articles as are applied to submissions from more traditional fields of horticultural science. 


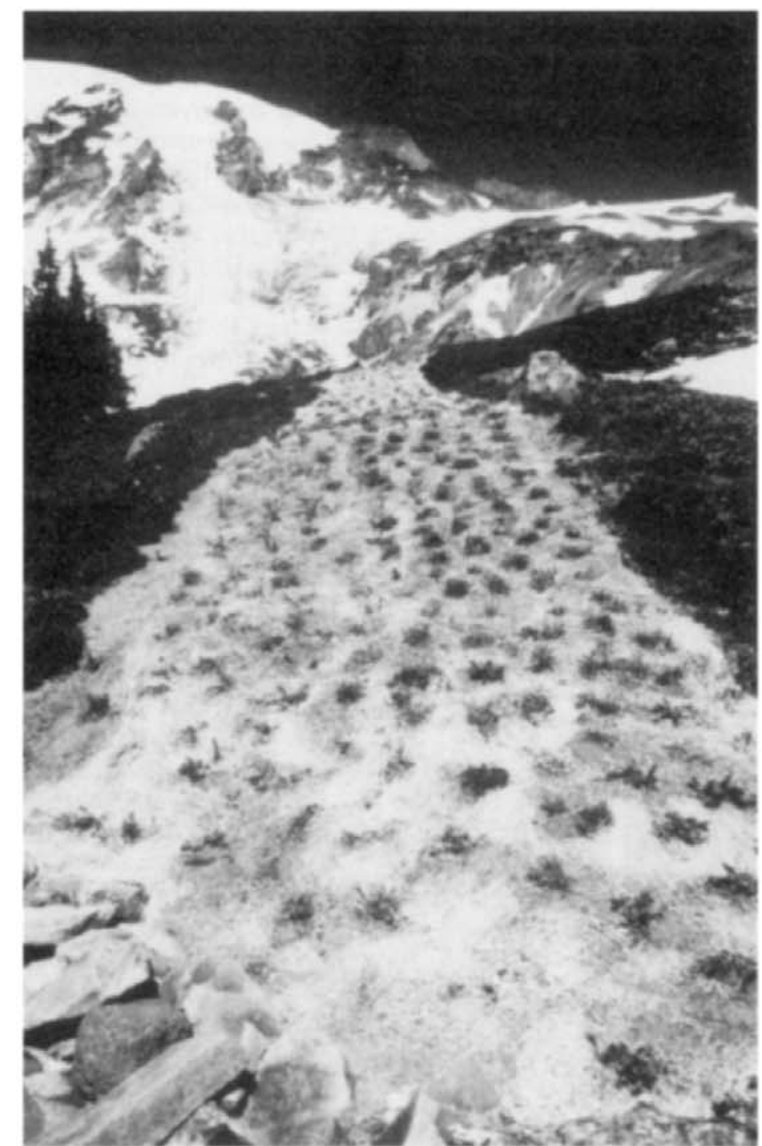

Fig. 3. Excelsior (slender curved wood shavings) is used as a mulch in mountain meadow revegetation projects at Mount Rainier National Park; native plants are propagated off-site then flown in by helicopter.

- Develop research programs in conservation horticulture that deal with endangered species of our states and regions, and encourage students to participate in these projects.

- Educate funding agencies, university administrators, and the general public concerning the contribution that horticultural science can make to conservation efforts, and the benefits that all parties can accrue from this participation.

This article is intended to encourage discussion within our Society and to provide some examples of conservation horticulture for those unfamiliar with the field. Individuals with an interest in this subject are encouraged to contact me (affolter@uga.cc.uga.edu) to share information and to begin building a network within ASHS to encourage further participation of Society members in conservation research. Initial sources to consult for more information about rare and endangered plants in your region include state Natural Heritage Programs (for information write: The Nature Conservancy, Conservation Science Division, 1815 N. Lynn St., Arlington, VA 22209; telephone 703-841-5300) and the Center for Plant Conservation (write: Center for Plant Conservation, Missouri Botanical Garden, P.O. Box 299, St. Louis, MO 631660299; telephone 314-577-9450; http:// www.mobot.org/CPC).

\section{Literature Cited}

Affolter, J.M. and M. Lagrotteria. 1995. Sustainable production of native aromatic and medicinal herbs in Cordoba Province, Argentina. HortScience 30:893. (Abstr.)

Anthony, J.L. 1992. In vitro propagation of Drosera spp. HortScience 27:850.

Aplet, G.H. and R.D. Laven. 1993. Relative performance of four Hawaiian shrubby plants (Asteraceae) under greenhouse conditions with implications for rarity. Biol. Conservation 65:1521.

Ayensu, E.S. and R.A. DeFilipps. 1978. Endangered and threatened plants of the United States. Smithsonian Inst. and World Wildlife Fund, Washington, D.C.

Bir, R.E. 1996. These natives are getting restless. American Nurseryman 183(8):33-34, 36-41.

Bogers, R.J. and P.J. van Leeuwen. 1992. The protection of wild bulbs and the propagation of specialty bulbs in Turkey. Acta Hort. 325:821829.

Bonati, A. 1991. Industry and the conservation of medicinal plants, p. 141-145. In: O. Akerele, V. Heywood and H. Synge (eds.). The conservation of medicinal plants. Cambridge Univ. Press, Cambridge, U.K.

Botanic Gardens Conservation Secretariat. 1989. The botanic gardens conservation strategy. International Union for the Conservation of Nature and Botanic Gardens Conservation Secretariat, Kew, Richmond, U.K.

Bunn, E. and K.W. Dixon. 1992. In vitro propagation of the rare and endangered Grevillea scapigera (Proteaceae). HortScience 27:261262.

Center for Plant Conservation. 1994. An action plan for conserving Hawaiian plant diversity. Missouri Bot. Garden, St. Louis.

Clayton,P.W.,J.F. Hubstenberger, and G.C.Phillips. 1990. Micropropagation of members of the Cactaceae Subtribe Cactinae. J. Amer. Soc. Hort. Sci. 115:337-343.

Del Tridici, P. 1987. Lost and found: Elliottia racemosa. Arnoldia 47(4):3-8.

Elias, T.S. (ed.). 1987. Conservation and management of rare and endangered plants. Calif. Native Plant Society, Sacramento, Calif.

Environmental Data Research Institute. 1995. Environmental grantmaking foundations. 3rd. ed. Environ. Data Res. Inst., Rochester, N.Y.

Falk, D.A. 1987. Integrated conservation strategies for endangered plants. Natural Areas J. 7(3):118123.

Falk, D.A. 1990. Integrated strategies for conserving plant genetic diversity. Ann. Missouri Bot. Garden 77:38-47.

Falk, D.A. and K.E. Holsinger (eds.). 1991. Genetics and conservation of rare plants. Oxford Univ. Press, New York.

Fuller, D.O. 1991. Medicine from the wild: An overview of the U.S. native medicinal plant trade and its conservation implications. World Wildlife Fund, Washington, D.C.

Given, D.R. 1994. Principles and practice of plant conservation. Timber Press, Portland, Ore.

Hensley, D. 1993. Are you keeping up with trends in the business? Nursery Manager 9(5):70-71.

Heywood, V.H. and P.S.W. Jackson (eds.). 1991. Tropical botanic gardens: Their role in conservation and development. Academic, New York.

Holsinger, K.E. and L.D. Gottlieb. 1991. Conservation of rare and endangered plants: Principles and prospects, p. 195-208. In: D.A. Falk and K.E. Holsinger (eds.). Genetics and conservation of rare plants. Oxford Univ. Press, New York.

Koller, G. 1992. Native dictates. Amer. Nurseryman 175(11):32-37.

Martin, D. 1993. The Lake Wales Ridge National Wildlife Refuge: Preserving a treasure trove of biodiversity. Endangered Species Tech. Bul. 18(4):3-4.

Martinez, H. 1995. The great native controversy. Nursery Management and Production 11(7):48$49,53-55$.

National Wildflower Research Center. 1992. Wildflower handbook. 2nd ed. Voyageur Press, Stillwater, Minn.

New England Wild Flower Society, Inc. 1992. New England Plant Conservation Program. Wild Flower Notes 7:1-79.

Palevitch, D. 1991. Agronomy applied to medicinal plant conservation, p. 167-178. In: O. Akerele, V. Heywood, and H. Synge (eds.). The conservation of medicinal plants. Cambridge Univ. Press, Cambridge, U.K.

Phillips, O. and B. Meilleur. 1995. Survey by CPC reveals "extraordinary" contributions of wild plants to U.S. economy. Diversity 11(3):10-11.

Raven, P.H. 1987. The scope of the plant conservation problem world-wide, p. 19-29. In: D. Bramwell, D.O. Hamann, V. Heywood, and H. Synge (eds.). Botanic gardens and the world conservation strategy. Academic, London.

Ray, G. 1995. CPC Hawaii office devises survival plan for 110 plants on the brink of extinction. Plant Conservation 9(2): 1-2.

Roberts, L. 1988. Extinction imminent for native plants. Science 242:1508.

Ruter, J.M., G. Krewer, and W.R. Faircloth. 1995. A 


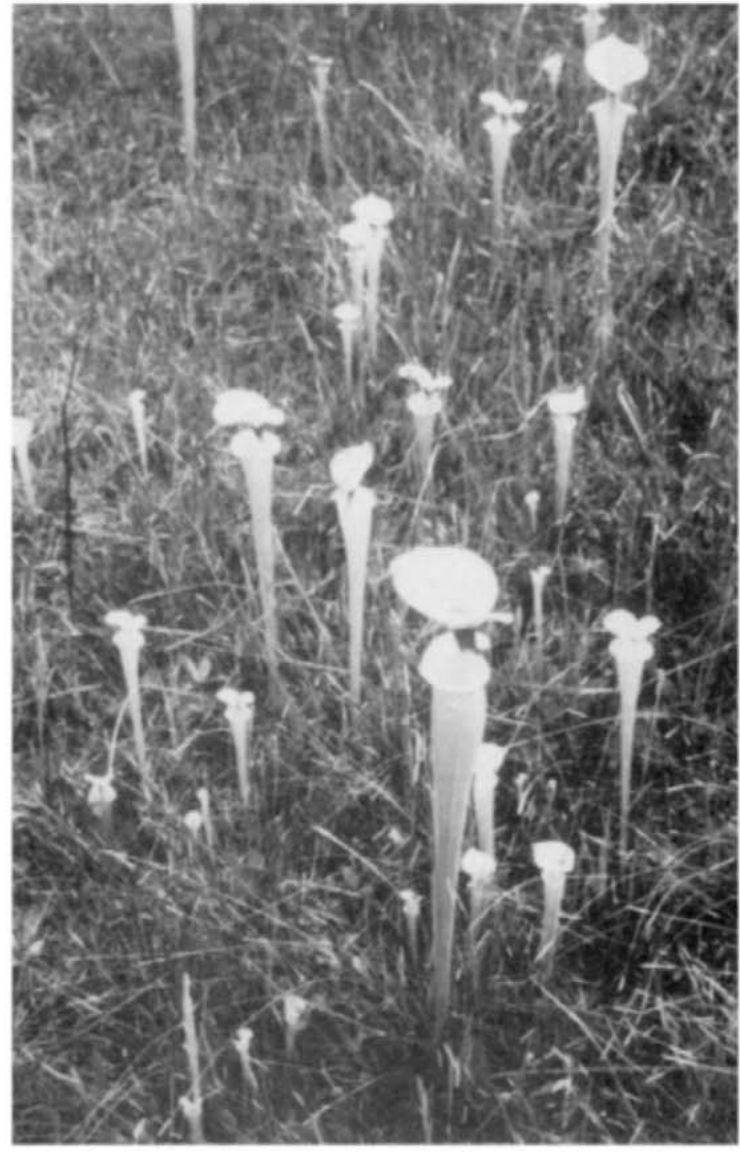

Fig. 4. Sarraceniaflava L. (golden trumpet) is one of several species of pitcherplant native to the coastal plain of Georgia; conservation of bog communities requires collaboration among horticultural scientists, ecologists, and land managers.

new location for Elliottia racemosa Muhl. ex Ell. (Ericaceae) in southwest Georgia. Castanea 60:370-371

Sampson, J.F., S.D. Hopper, and S.H. James. 1988. Genetic diversity and the conservation of Eucalyptus crucis Maiden. Austral. J. Bot. 36:447-60.

Sauer, L. 1995a. Native plant restoration: Part I. American Nurseryman 182(1):90-94, 96-99.

Sauer, L. 1995b. Native plant restoration: Part II. Amer. Nurseryman 182(2):47-51.

Simmons, J.B., R.I. Beyer, P.E. Brandham, G. Ll. Lucas, and V.T.H. Parry (eds.). 1976. Conserva- tion of threatened plants. Plenum Press, New York.

Synge, H. (ed.). 1981. The biological aspects of rare plant conservation. Wiley, New York.

The Nature Conservancy. 1996. Priorities for conservation: 1996 annual report card for U.S. plant and animal species. The Nature Conservancy, Arlington, Va.

Thomas, S.H. 1993a. Hanging basket grower adds natives to line. Nursery Manager 9(3):82.

Thomas, S.H. 1993b. Florida's mix of residents a challenge for natives market. Nursery Manager 9(3):84.

Thomson, K.S. 1990. Benjamin Franklin's lost tree. Amer. Scientist 78:203-206.

Topik, C. 1994. The national forest system rare plant conservation program. Endangered Species Tech. Bul. 19(4):15-17.

U.S. Fish and Wildlife Service. 1995. Box score: listings and recovery plans as of October 31 , 1995. Endangered Species Tech. Bul. 20(6):36.

Van de Water, J. 1995. The native debate. American Nurseryman 182(12):58-66.

Wagner, W.L., D.R. Herbst, and S.H. Sohmer. 1990. Manual of the flowering plants of Hawaii. vol. 1. Bishop Museum, Honolulu.

Wallace, S. 1990. Central Florida scrub: Trying to save the pieces. Endangered Species Update 8(1):59-61.

Wallace, S. 1995. Collecting rare species in Florida, p. 685-689. In: L. Guarino, V. Ramanatha Rao, and R. Reid (eds.). Collecting plant genetic diversity: Technical guidelines. CAB Intl., Wallingford, Oxon, United Kingdom.

Wieland, G.D. 1995. Guidelines for the management of orthodox seeds. Center for Plant Conservation, St. Louis, Mo.

Wilson, J. 1993. The impasse in wildflower seed production. Wildflower 6(1):7-9.

Winter, J.H.S. and D.J. Botha. 1994. The release of endangered plants in the horticultural trade: Conservation or exploitation? Biodiversity and Conservation 3:142-147.

Yatskievych, G. and R.W. Spellenberg. 1993. Plant conservation, p. 207-226. In: N.R. Morin (ed.). Flora of North America. vol. 1. Oxford Univ. Press, New York. 